\title{
Excretion of organic carbon by phytoplankton: its relation to algal biomass, primary productivity and bacterial secondary productivity in the Baltic Sea
}

\author{
Risto Lignell*
}

Tvärminne Zoological Station, SF-10900 Hanko, Finland

\begin{abstract}
In 1985, algal biomass, primary productivity (incorporation of ${ }^{14} \mathrm{C}$, acidified water sample), excretion of organic matter (exudation), and bacterial secondary productivity were followed off the SW coast of Finland, in the nothern Baltic Sea. Molecular size fractionation of the dissolved (net) excreted organic carbon pool $\left(\mathrm{EOC}_{\mathrm{n}}\right.$ ) was carried out by gel filtration. During the phytoplankton growth season the mean algal standing stock was $0.54 \mathrm{~g} \mathrm{C} \mathrm{m}^{-2}$, and picoalgae $(<2 \mu \mathrm{m})$ represented on average $17 \%$ of the total algal biomass. The primary production was $84.2 \mathrm{~g} \mathrm{C} \mathrm{m}^{-2} \mathrm{yr}^{-1}$. Annual EOC $\mathrm{E}_{\mathrm{n}}$ and total exudation ( $E O C_{n}$ plus bacterial uptake of exudates) values amounted to 4.6 and $7.1 \%$ of primary production; at the same time, the net and total exudation averaged 7.5 and $10.8 \%$ of the current phytoplankton carbon biomass per day. Net bacterial production in the trophogenic layer was $12.1 \mathrm{~g}$ $\mathrm{C} \mathrm{m}^{-2} \mathrm{yr}^{-1}$ ( ${ }^{3} \mathrm{H}$-thymidine method) or $38.4 \mathrm{~g} \mathrm{C} \mathrm{m}^{-2} \mathrm{yr}^{-1}$ (dark ${ }^{14} \mathrm{CO}_{2}$ uptake); hence, assuming an assimilation efficiency of $50 \%$, bacteria were able to satisfy 25 or $8 \%$ of their carbon demand via exudate uptake. Throughout the productive period, $\mathrm{EOC}_{\mathrm{n}}$ consisted mainly of compounds of 300 to 600 daltons; larger compounds ( 1500 and $>10000$ daltons) were also observed. On the basis of the size of the excreted compounds, exudation probably took place via mediated transport across the algal cell membrane, rather than via passive leakage from the cell.
\end{abstract}

\section{INTRODUCTION}

Until the mid 1970's, bacterioplankton was regarded as a minor factor in oceanic food webs, and virtually all phytoplankton production was assumed to be grazed by large zooplankton (Steele 1974). Evidence to the contrary started to accumulate with the findings that bacteria may comprise a major fraction of the biomass of the heterotrophic planktonic compartment (Sieburth et al. 1978, Sorokin 1978) and that they have a reactive surface area larger than that of the rest of the plankton community (Williams 1981, 1984). Although only a small proportion of the bacteria may be active under natural conditions (range 1 to $85 \%$; Fuhrman \& Azam 1982, Pedrós-Alió \& Newell 1989), their production in the trophogenic layer of various aquatic environments has been found to average $20 \%$ of primary production, or about twice the production of the macrozooplankton (Cole et al. 1988).

\footnotetext{
- Present address: Dept of Limnology, Helsinki University, E-talo, SF-00710 Helsinki, Finland
}

There is still some controversy about the role of bacteria in aquatic food webs, as reported carbon conversion efficiencies have ranged from below $10 \%$ to almost $100 \%$; higher efficiencies have generally been found with small molecules easily taken up by bacteria (e.g. glucose and amino acids), while lower efficiencies seem to be associated with more refractory compounds (e.g. phytoplankton detritus and the main pool of aquatic dissolved organic carbon) (see Williams 1984, Bjørnsen 1986).

Phytoplankton primary production does not always seem to be able to supply the carbon required by the heterotrophic community (e.g. Sieburth 1977, Scavia \& Laird 1987). At times the problem may be only apparent, since organic carbon produced by phytoplankton may recycle effectively within the aquatic food web, and algal photosynthesis can thus satisfy a carbon demand that considerably exceeds the primary productivity (Strayer 1988).

In contrast to the cycling of organic carbon, community respiration cannot exceed substrate inputs. The major part of oxygen consumption has frequently been found to be associated with heterotrophs in the $<10$ 
and $<1 \mu \mathrm{m}$ size fractions (Williams 1982, Smith et al. 1986, Hopkinson et al. 1989), reflecting the great importance of small heterotrophs, especially bacteria, in the overall plankton metabolism.

An important question involves the sources of organic carbon for bacterioplankton. Hagström \& Larsson (1984) found significant diel changes in bacterial growth rates with higher values during daylight hours. Moreover, in an extensive review comprising 70 studies from various marine and freshwater environments, Cole et al. (1988) found bacterial productivity to be best explained by phytoplankton primary productivity. These results indicate a close link between the 2 processes. A potential source of newly synthesized organic carbon for bacteria is excretion of organic matter by algae (Wiebe \& Smith 1977, Larsson \& Hagström 1979, Coveney 1982, Lancelot 1984), and commonly accepted values for percentage exudate release (PER) range from around $5 \%$ of primary productivity (eutrophic waters) to about $40 \%$ (oligotrophic waters; Fogg 1983). Thus, exudation serves as a major candidate for coupling algal primary productivity and bacterial secondary productivity in the pelagial, though the excretion of dissolved organic carbon during zooplankton feeding (Lampert 1978, Williams 1981, Jumars et al. 1989) cannot be ruled out.

In the present study, the importance of algal exudation for the carbon budgets of phyto- and bacterioplankton was investigated. The nature and ecological significance of the exudation process will be discussed on the basis of the size distribution of the excreted compounds.

\section{MATERIAL AND METHODS}

In 1985, the annual course of phytoplankton exudation and its relationship to algal biomass primary productivity and bacterial secondary productivity were studied off the SW coast of Finland. In 1986 to 1988, experiments designed to provide supplementary information were carried out.

From 5 to 19 May 1985, the sampling/in situ incubation station was located at Tvärminne Storfjärd, Finland, and after that (with the arrival of a moored buoy) it was at Långskär, about $4 \mathrm{~km}$ south of Storfjärden towards the open sea. Both stations are 30 to $40 \mathrm{~m}$ deep, and lie in the outer Tvärminne archipelago, facing the Northern Baltic proper. The area is not affected by large sewage outlets. Salinity and $\mathrm{pH}$ are about $6 \%$ and 8 , respectively, and the area is characterized by occasional inflows of low-saline surface water from the inner archipelago or of cold, more saline Baltic deep water originating from upwellings. A detailed description of the hydrography and phytoplankton ecology in the area is presented in Niemi (1975).
In 1985, during a phytoplankton production period of 194 d, 27 experiments were carried out at fairly short intervals during the spring and late summer blooms. A pooled sample taken from every ${ }^{14} \mathrm{C}$ incubation depth (two 2.51 Ruttner samples per depth) was used for all measurements. Cumulative irradiance values were measured with a Kipp \& Zonen light meter (Holland). Before samplings, the depths of the euphotic $\left(Z_{\mathrm{eu}}\right)$ and mixed layers (thermocline) were measured. $Z_{\text {eu }}$ was determined either with a Mavolux underwater light meter (Germany) or from the Secchi depth (Sr), using an empirical formula for the area (Niemi 1975):

$$
\mathrm{Z}_{\text {eu }}=3.43 \mathrm{Sr}^{0.75}
$$

When both methods were used simultaneously, the obtained $Z_{\text {eu }}$ values matched well.

Primary productivity measurements. The upper 3 to $5 \mathrm{~m}$ (range 2 to $12 \mathrm{~m}$ ) of the euphotic layer (about $10 \mathrm{~m}$ deep) was usually covered with 3 or 4 (range 2 to 9) sampling/incubation depths. Areal photosynthesis was calculated by trapezoid integration. Moreover, in 4 cases the areal photosynthesis was computed from measurements carried out at $1 \mathrm{~m}$ depth, using the formula (Lehman et al. 1975):

$$
\mathrm{P}(\mathrm{I})=\mathrm{P}_{\max }\left(\mathrm{I} / \mathrm{I}_{\mathrm{opt}}\right) \exp \left(1-\mathrm{I} / \mathrm{I}_{\mathrm{opt}}\right)
$$

where $\mathrm{P}_{\max }=$ maximum photosynthetic rate occurring at $\mathrm{I}_{\text {opt; }} \mathrm{I}=$ light intensity at a given depth; and $\mathrm{I}_{\mathrm{opt}}=$ light intensity at which the photosynthetic rate is saturated. On sunny days, $\mathrm{P}_{\max }$ almost occurred always at about $1 \mathrm{~m}$ depth, and thus, reliable values for primary productivity on an areal basis were obtained in both calculations.

Primary productivity was measured by the ${ }^{14} \mathrm{C}$ method (Steemann Nielsen 1952). $\mathrm{NaH}^{14} \mathrm{CO}_{3}$ at $5 \mu \mathrm{Ci}$ (the specific activity of the undiluted stock was 57.8 $\mathrm{mCi} \mathrm{mmol}{ }^{-1}$; Amersham, UK) was added to $100 \mathrm{ml}$ glass bottles. In 1985, duplicate light bottles were used at each incubation depth (in 1986, 5 replicates at $1 \mathrm{~m}$ ) and one triplicate set of dark and blank $(0.5 \mathrm{ml} 38 \%$ formalin per $100 \mathrm{ml}$ ) bottles at $2 \mathrm{~m}$. The incubations were started between 10:00 and 11:00 h and lasted for 6 to $7 \mathrm{~h}$.

All radioactivity measurements were performed with a LKB Rackbeta 1215 liquid scintillation counter (LKBWallac, Finland), using the external standard channel ratio method. In all ${ }^{14} \mathrm{C}$ primary productivity and exudation calculations the dark values were subtracted from the corresponding light values. Dissolved inorganic carbon was measured with an infra-red carbon detector (Elektro-Dynamo carbon analyzer, Laitila, Finland).

Size-fractionation of ${ }^{14} \mathrm{C}$ samples: Primary productivity (particulate plus dissolved organic ${ }^{14} \mathrm{C}$ ) was measured by allowing an acidified $4 \mathrm{ml}$ subsample $(\mathrm{pH}<2)$ 
to stand open for $24 \mathrm{~h}$ (no bubbling), before the PCS scintillation cocktail (Amersham) was added (Niemi et al. 1983).

In order to ensure gentle removal of algal cells from the water phase, the net excreted organic carbon pool $\left(E C_{n}\right)$ was measured on the supernatant of a centrifuged sample $(20 \mathrm{~min}$ at $3000 \times \mathrm{g}$, in situ temperature), corrected for particulate $(>0.2 \mu \mathrm{m})$ organic ${ }^{14} \mathrm{C}$ in that fraction (Lignell \& Kuosa 1988).

In order to avoid algal fragments in the bacterial size fraction $(0.2$ to $0.8 \mu \mathrm{m})$, its total organic ${ }^{14} \mathrm{C}$ content was determined as the difference between parallel filtrations on $0.2 \mu \mathrm{m}$ cellulose acetate filters (Sartorius) and $0.8 \mu \mathrm{m}$ (in spring $1.0 \mu \mathrm{m}$ due to greater bacterial size) polycarbonate filters (Nuclepore) (but see 'Results'!). A pressure differential of $<50 \mathrm{~mm} \mathrm{Hg}$ was used in the former filtrations and a considerably more gentle suction in the latter (resulting in about equal filtration times). The filters were rinsed once with filtered (Whatman GF/F) seawater and then acidified and allowed to stand overnight in scintillation vials before the measurement of radioactivity.

In 1985, filtration treatments were carried out with all samples, whereas net exudation was usually measured on samples from only one depth (1 or $2 \mathrm{~m}$ ).

In 1986, autotrophic productivity in the 0.2 to $0.8 \mu \mathrm{m}$ fraction $(<0.8 \mu \mathrm{m}$ prefiltered sample, pressure differential as above) was measured, and bacterial incorporation of ${ }^{14} \mathrm{C}$ via exudate uptake was evaluated by correcting the total organic ${ }^{14} \mathrm{C}$ in this fraction for autotrophic productivity. In 1988 , the organic ${ }^{14} \mathrm{C}$ in the $<0.8 \mu \mathrm{m}$ filtrate was also measured.

Bacterial secondary productivity. ${ }^{3} \mathrm{H}$-thymidine method: Net bacterial productivity was measured from tritiated thymidine incorporation (TTI) into material precipitable with cold trichloroacetic acid (TCA) (Fuhrman \& Azam 1982). A saturating (10 nmol; Bell 1986) concentration of ${ }^{3} \mathrm{H}$-thymidine (specific activity 38 to $44 \mathrm{Ci} \mathrm{mmol}^{-1}$, Amersham) was added to $20 \mathrm{ml}$ scintillation vials ( 2 to 3 samples and 1 to 2 formalin-killed blanks). The TTI incubations were performed in situ at $1 \mathrm{~m}$ depth; they were started simultaneously with ${ }^{14} \mathrm{C}$ incubations, and after about $2 \mathrm{~h}$ they were terminated with formalin ( $200 \mu \mathrm{l}$ of $38 \%$ formalin to $20 \mathrm{ml})$. Subsamples $(5 \mathrm{ml})$ were extracted for 0.5 to $1 \mathrm{~h}$ with $5 \mathrm{ml}$ $10 \%$ TCA in ice-cold conditions and then filtered on $0.2 \mu \mathrm{m}$ cellulose acetate filters (Sartorius). The filters were rinsed with $5 \%$ ice-cold TCA before radioactivity measurements.

Net bacterial productivity was calculated, using bacterial cell volumes of $0.063 \mu \mathrm{m}^{3}$ (spring; Kuparinen 1988) and $0.045 \mu \mathrm{m}^{3}$ (summer-autumn; Kuparinen unpubl.), a ${ }^{3} \mathrm{H}$-thymidine conversion factor of $1.1 \times 10^{18}$ cells $\mathrm{mol}^{-1}$ (Riemann et al. 1987), and a carbon content of $0.27 \mathrm{pg} \mathrm{C} \mu \mathrm{m}^{-3}$ (Kuparinen 1988).
Dark ${ }^{14} \mathrm{CO}_{2}$ uptake method: Dark uptake of inorganic ${ }^{14} \mathrm{C}$ in the 0.2 to $0.8 \mu \mathrm{m}$ (in spring 0.2 to $1.0 \mu \mathrm{m}$ ) size fraction (calculated as the difference, blank values subtracted) was transformed to bacterial productivity by assuming that bacteria obtain $6 \%$ of the total assimilated carbon through anaplerotic uptake of ${ }^{14} \mathrm{CO}_{2}$ (Sorokin 1965, Kuznetsov \& Romanenko 1966). The values were corrected for the proportion of attached and large $(>0.8 \mu \mathrm{m})$ bacteria.

Fractionation of bacterial heterotrophic activity: The proportion of attached and large bacteria was determined from total ${ }^{3} \mathrm{H}$-thymidine incorporation (no TCA extraction, blank values subtracted): $5 \mathrm{ml}$ subsamples were filtered in parallel on 0.2 and $0.8 \mu \mathrm{m}$ (in the spring $1.0 \mu \mathrm{m}$ ) filters; the filters were rinsed twice with $10 \mathrm{ml}$ filtered seawater before the radioactivity measurements.

Size-fractionation of dissolved exudates. Samples for gel filtration $\left(20 \mu \mathrm{Ci} \mathrm{NaH}{ }^{14} \mathrm{CO}_{3}\right.$ added to $\left.110 \mathrm{ml}\right)$ were incubated in glass bottles for 6 to $8 \mathrm{~h}$ in situ. After incubation, the samples were centrifuged, and the $<0.2 \mu \mathrm{m}$ filtrates of the supernatant (the $\mathrm{EOC}_{\mathrm{n}}$ pool) were acidified and bubbled with $\mathrm{N}_{2}$ for $1 \mathrm{~h}$; the samples were then neutralized and frozen $\left(-20^{\circ} \mathrm{C}\right)$ for storage.

Sephadex G-15 and G-50 gels (fine grade, Pharmacia, Sweden) with separation ranges of 0 to 1500 and 1500 to 30000 daltons, respectively, were used for the size fractionation of the dissolved exudates. Distilled water with $0.3 \% \mathrm{NaCl}$ and $0.02 \% \mathrm{NaN}_{3}$ was used as eluent (Anon 1977). The gel columns $(2.6 \times 38 \mathrm{~cm})$ were calibrated at $1 \mathrm{ml}$ elution intervals with compounds of known molecular weight (Table 6; see Stabel 1977). In principle, each compound comes out of the column in an elution volume that corresponds to its molecular weight (actually size).

Before gel filtration, the frozen ${ }^{14} \mathrm{C}$ samples were thawed and concentrated in a Rotavapor to $4 \mathrm{ml}$ in room temperature. The concentrate was filtered through a $0.2 \mu \mathrm{m}$ filter and $2 \mathrm{ml}$ of it was then eluted through each column. The radioactivity of the eluted fractions was measured similarly to that of the primary productivity samples.

Phytoplankton identification and enumeration and chlorophyll a determinations. Large algae were determined on acid Lugol-preserved samples by the method presented by Utermöhl (1958), using phase contrast microscopy (Leitz Diavert, Germany). Picoalgae $1<2$ $\mu \mathrm{m})$ were counted with epifluorescence microscopy (Davis \& Sieburth 1982) on unpreserved samples (stored in refrigerator at $+4{ }^{\circ} \mathrm{C}$ ) within 1 to $2 \mathrm{~d}$ of sampling; the proportion of picoplanktonic forms passing $0.8 \mu \mathrm{m}$ filters (in spring $1.0 \mu \mathrm{m}$ ) was also determined. Wet weight values were transformed to carbon values using a coefficient of 0.1 . The nomenclature follows Edler et al. (1984). 
Chlorophyll a was measured with a Turner 111 fluorometer (calibrated with pure chlorophyll a), using Whatman GF/F filters and $24 \mathrm{~h}$ ethanol extraction (Wintermans \& Demots 1965).

\section{RESULTS}

\section{Algal succession}

On 7 May 1985, 10 d after the break-up of the icecover in Tvärminne archipelago, phytoplankton biomass and chlorophyll a reached their annual maxima (742 $\mathrm{mg} \mathrm{C} \mathrm{m}^{-3}$ and $39 \mathrm{mg} \mathrm{m}^{-3}$; Fig. 1). At the same time, the primary productivity reached its highest value of $2.37 \mathrm{~g} \mathrm{C} \mathrm{m}^{-2} \mathrm{~d}^{-1}$ (Fig. 2). The spring bloom consisted mainly of diatoms: during the peak the algal community consisted predominantly of Achnantes taeniata, while towards the end of the bloom Skeletonema costatum became more important (Table 1). The bloom lasted for $1 \mathrm{mo}$, and the integral primary production during this period was $30.8 \mathrm{~g} \mathrm{C} \mathrm{m}^{-2}$ or $36.5 \%$ of the corresponding value for the whole productive period of 6.5 mo (Table 2).

The summer minimum period started from the beginning of June, and small species $(<20 \mu \mathrm{m})$, mainly flagellates, dominated (Table 1). This period was characterized by low biomass, chlorophyll $a$ and primary productivity (Figs. 1 and 2).

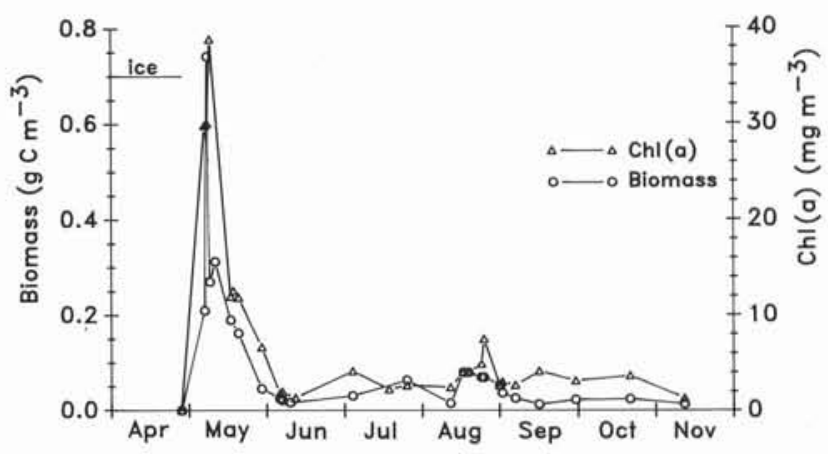

Fig. 1. Annual course of phytoplankton biomass and chlorophyll $a$ in the Tvärminne archipelago in 1985

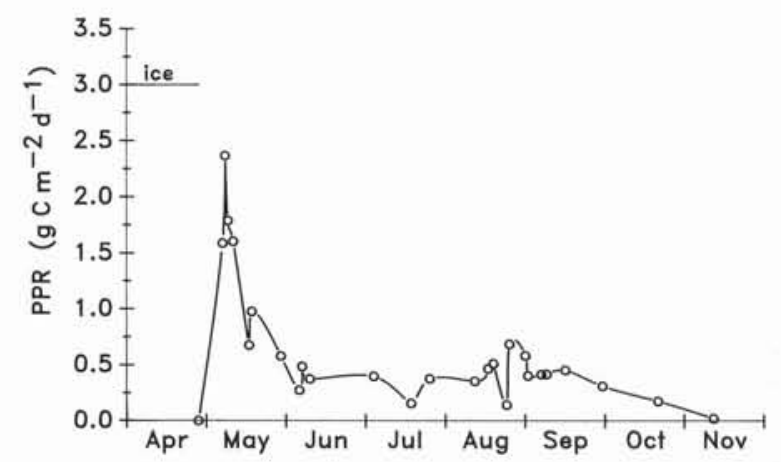

Fig. 2. Annual course of primary productivity (PPR) in the Tvärminne archipelago in 1985

Table 1. Dominant species during the phytoplankon succession in the Tvärminne archipelago in 1985

\begin{tabular}{|llc|}
\hline Period & \multicolumn{1}{c}{ Dominant species } & $\%$ Biomass \\
\hline 6-10 May & Achnantes taeniata Grunow & 70 \\
16-17 May & Chaetoceros holsaticus Schütt & 20 \\
& C. wighamii Brightwell & 10 \\
& A. taeniata & 10 \\
& Skeletonema costatum (Greville) Cleve & 10 \\
& Pyramimonas spp. & 10 \\
28 May & S. costatum & 37 \\
& Eutreptiella gymnastica Throndsen & 33 \\
4-12 Jun & Pseudopedinella elastica Skuja & 35 \\
& Dinophysis acuminata (Claparéde \& Lachmann) & 20 \\
2-23 July & Cryptomonas spp. & $17-27$ \\
& S. costatum & $11-20$ \\
& Chrysochromulina spp. & $10-16$ \\
& Microcystis reinboldii (Richter) Forti & $9-13$ \\
9 Aug & Achroonema spp. & $5-19$ \\
& Pedinella tricostata Rouchijajnen & 20 \\
14-29 Aug & Nannochloropsis sp. & 20 \\
3 Sep-7 Nov & Aphanizomenon flos-aquae (L.) Ralfs ex Bornet \& Flahault & $40-80$ \\
& Cryptomonas spp. & $10-40$ \\
& Katodinium rotundatum (Lohmann) Fott & $<10-30$ \\
\end{tabular}


In the latter half of August, the blue-green alga Aphanizomenon flos-aquae formed a minor peak with maximum biomass, chlorophyll $a$ and primary productivity values of $80 \mathrm{mg} \mathrm{C} \mathrm{m}^{-3}, 7.5 \mathrm{mg} \mathrm{m}^{-3}$ and $683 \mathrm{mg} \mathrm{C}$ $\mathrm{m}^{-2} \mathrm{~d}^{-1}$, respectively (Figs. 1 and 2). In the beginning of September, small flagellates and Nannochloropsis sp. became dominant again (Table 1), and the algal assemblage started to decline to the negligible winter levels (Figs. 1 and 2).

In 1985, picoplankton biomass was on average $16.7 \%$ of total algal biomass, ranging from $1 \%$ in the spring to $26 \%$ in the autumn (Table 3). Microscopical examinations revealed that 30 to $50 \%$ of the picoplanktonic algae passed $0.8 \mu \mathrm{m}$ filters (Fig. 3 ).

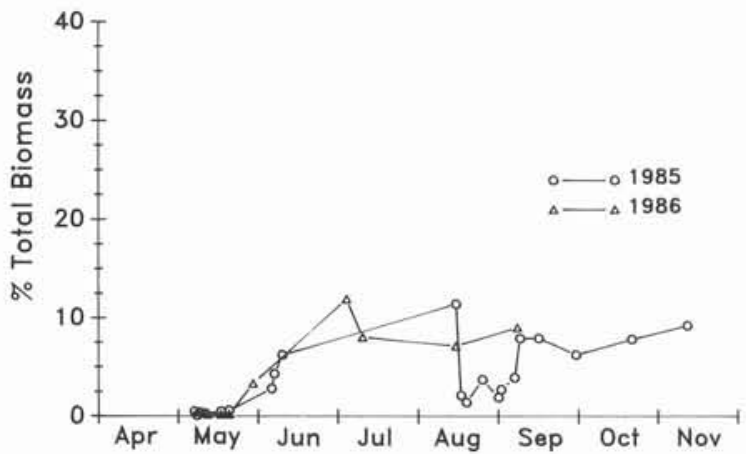

Fig. 3. Proportion of algal cells passing $0.8 \mu \mathrm{m}$ filters (in spring $1.0 \mu \mathrm{m})$ in the Tvärminne archipelago

Table 2. Total seasonal values for algal primary production and exudation, and bacterial secondary production in the Tvärminne archipelago in 1985. PPR: primary production; $\mathrm{EOC}_{n}$ and $\mathrm{EOC}_{t}$ : net and total exudation; baterial secondary productivity was measured by ${ }^{3} \mathrm{H}$-thymidine method (TTI) and dark ${ }^{14} \mathrm{CO}_{2}$ uptake. Values in brackets are as follows: PPR: number of experiments (n); $\mathrm{EOC}_{\mathrm{n}}$ and $\mathrm{EOC}_{\mathrm{t}}: \%$ PPR; TTI and dark ${ }^{14} \mathrm{CO}_{2}: 1 \mathrm{st}=\mathrm{n}, 2 \mathrm{nd}=\% \mathrm{PPR}$

\begin{tabular}{|c|c|c|c|c|c|c|}
\hline \multirow[t]{2}{*}{ Season } & \multirow[t]{2}{*}{ Days } & \multicolumn{3}{|c|}{ Algal primary production } & \multicolumn{2}{|c|}{ Bacterial production } \\
\hline & & $\begin{array}{c}\mathrm{PPR} \\
\left(\mathrm{g} \mathrm{C} \mathrm{m}^{-2}\right)\end{array}$ & $\begin{array}{c}\mathrm{EOC}_{\mathrm{n}} \\
\left(\mathrm{g} \mathrm{C} \mathrm{m}^{-2}\right)\end{array}$ & $\begin{array}{c}\mathrm{EOC}_{\mathrm{t}} \\
\left(\mathrm{g} \mathrm{C} \mathrm{m}^{-2}\right)\end{array}$ & $\begin{array}{c}\text { TTI } \\
\left(\mathrm{g} \mathrm{C} \mathrm{m}^{-2}\right)\end{array}$ & $\begin{array}{c}\operatorname{Dark}^{14} \mathrm{CO}_{2} \\
\left(\mathrm{~g} \mathrm{C} \mathrm{m}^{-2}\right)\end{array}$ \\
\hline Spring & 31 & $30.8[7]$ & $0.58[1.9]$ & $1.45[4.7]$ & $1.75[3] \quad(5.7)$ & $6.65[2] \quad(21.6)$ \\
\hline Summer & 73 & $25.8[7]$ & $2.05[8.0]$ & $2.62[10.1]$ & $6.73[6] \quad(26.1)$ & $12.83[4] \quad(49.8)$ \\
\hline Late summer & 20 & $9.3[6]$ & $0.62[6.7]$ & $0.83[8.8]$ & $1.66[3] \quad(17.8)$ & $9.00[6] \quad(96.4)$ \\
\hline Autumn & 70 & $18.3[6]$ & $0.64[3.5]$ & $1.11[6.0]$ & $1.96[5] \quad(10.7)$ & $9.92[6] \quad(54.1)$ \\
\hline Total & 194 & $84.2[26]$ & $3.90[4.6]$ & $6.02[7.1]$ & $12.10[17](14.4)$ & $38.39[18](45.6)$ \\
\hline
\end{tabular}

Table 3. Average values for total and picoalgal $(<2 \mu \mathrm{m})$ standing stocks, and for daily algal exudation as percentage of the current total phytoplankton carbon biomass in the Tvärminne archipelago in 1985. \% Bm.: percentage of the current total algal standing stock; CV: coefficient of variation (\%)

\begin{tabular}{|c|c|c|c|c|c|c|c|c|c|c|}
\hline \multirow{2}{*}{$\begin{array}{l}\text { Period } \\
\text { Spring }\end{array}$} & \multirow{2}{*}{$\begin{array}{c}\text { Days } \\
31\end{array}$} & \multicolumn{2}{|c|}{$\begin{array}{c}\text { Total biomass } \\
\mathrm{mg} \mathrm{C} \mathrm{m}{ }^{-2}(\mathrm{CV}, \mathrm{n})\end{array}$} & $\begin{array}{r}<2 \mu \mathrm{m} \\
\mathrm{mg} \mathrm{C} \mathrm{m} \mathrm{m}^{-2}\end{array}$ & \multicolumn{2}{|c|}{$<2 \mu \mathrm{m}$ biomass } & \multicolumn{2}{|c|}{$\begin{array}{c}\text { Net exud. } \\
\% \mathrm{Bm} \cdot \mathrm{d}^{-1}(\mathrm{CV}, \mathrm{n})\end{array}$} & \multicolumn{2}{|c|}{$\begin{array}{c}\text { Total exud. } \\
\% \mathrm{Bm}^{-\mathrm{d}^{-1}}(\mathrm{CV}, \mathrm{n})\end{array}$} \\
\hline & & 1857 & $(82,7)$ & 15.4 & 1.0 & $(57,6)$ & 0.9 & $(-, 1)$ & 2.3 & $(-, 1)$ \\
\hline Summer & 73 & 295 & $(58,6)$ & 33.7 & 16.7 & $(36,4)$ & 12.7 & $(45,4)$ & 16.7 & $(39,4)$ \\
\hline Late summer & 20 & 660 & $(29,6)$ & 55.1 & 9.4 & $(48,6)$ & 3.8 & $(90,6)$ & 5.5 & $(56,6)$ \\
\hline Autumn & 70 & 167 & $(30,5)$ & 40.8 & 25.9 & $(36,5)$ & 6.1 & $(130,5)$ & 9.8 & $(99,5)$ \\
\hline Year & 194 & 536 & & 35.6 & 16.7 & & 7.5 & & 10.8 & \\
\hline
\end{tabular}

Table 4. Average phytoplankton biomass and productivity in the whole and prefiltered (spring: $<1.0 \mu \mathrm{m} ;$ summer $<0.8 \mu \mathrm{m}$ ) samples in the Tvärminne archipelago in 1986. Values in brackets: CV. Other explanations in Tables 2 and 4

\begin{tabular}{|c|c|c|c|c|c|c|}
\hline Period & $\mathrm{n}$ & $\begin{array}{l}\text { Tot. biom. } \\
\left(\mathrm{mg} \mathrm{C} \mathrm{m}^{-3}\right)\end{array}$ & $\begin{array}{c}\mathrm{PPR} \\
\left(\mathrm{mg} \mathrm{C} \mathrm{m}^{-3} \mathrm{~h}^{-1}\right)\end{array}$ & $\begin{array}{l}<2 \mu \mathrm{m} \text { biom. } \\
\left(\mathrm{mg} \mathrm{C} \mathrm{m}{ }^{-3}\right)\end{array}$ & $\begin{array}{l}\text { Pref. biom. } \\
\left(\mathrm{mg} \mathrm{C} \mathrm{m}^{-3}\right)\end{array}$ & $\begin{array}{c}\text { Pref. PPR } \\
\left(\mathrm{mg} \mathrm{C} \mathrm{m}^{-3} \mathrm{~h}^{-1}\right)\end{array}$ \\
\hline $\begin{array}{l}11 \text { May } \\
-19 \text { May } \\
\text { 2 Jul }\end{array}$ & 3 & $253 \quad[37]$ & $17.03 \quad[17]$ & $1.3[14]$ & $0.5[37]$ & $0.08 \quad[108]$ \\
\hline-12 Aug & 3 & $35 \quad[59]$ & $4.74 \quad[16]$ & $5.9[60]$ & $3.2[60]$ & 0.63 \\
\hline
\end{tabular}


In spring and summer 1986, the contribution of picoplanktonic algae to total phytoplankton biomass was similar to that in 1985 (Tables 3 and 4). The ratio of autotrophic productivity in the $<0.8 \mu \mathrm{m}$ prefiltered fraction to autotrophic productivity in the whole sample was 1.5 to 2 times as high as the corresponding algal biomass ratio (Table 4).

\section{Bacterial secondary productivity}

In spring 1985, the net bacterial productivity (TTI) started to increase more slowly than primary productivity (Fig. 4). In the summer, the net bacterial productivity varied between 0.21 and $0.62 \mathrm{mg} \mathrm{C} \mathrm{m}^{-3} \mathrm{~h}^{-1}$, and the bulk of the annual net bacterial production in the trophogenic layer took place during this period $\left(6.73 \mathrm{~g} \mathrm{C} \mathrm{m}^{-2}\right.$ or $56 \%$ of the total; Table 2). During the phytoplankton production periods in 1985 and 1986, the partial correlation of TTI with primary productivity (controlled for temperature) was significant, while the correlation with algal biomass was clearly lower (Table 5).

In 1985, bacterial productivity values measured with dark ${ }^{14} \mathrm{CO}_{2}$ uptake were usually considerably higher than those obtained with TTI (Fig. 4). The large variation in dark ${ }^{14} \mathrm{CO}_{2}$ uptake values compared to TTI values (Fig. 4) mainly reflected random error caused by the proximity of dark and blank values in the 0.2 to $0.8 \mu \mathrm{m}$ fraction.

In 1985, the integral net bacterial production measured with TTI was $12.1 \mathrm{~g} \mathrm{C} \mathrm{m}^{-2} \mathrm{yr}^{-1}$ or $14.4 \%$ of the primary production in the trophogenic layer, while the corresponding values obtained with dark ${ }^{14} \mathrm{CO}_{2}$ uptake were $38.4 \mathrm{~g} \mathrm{C} \mathrm{m}^{-2} \mathrm{yr}^{-1}$ and $45.6 \%$ (Table 2).

\section{Attached and free-living bacteria}

The proportion of large and attached bacteria retained on $0.8 \mu \mathrm{m}$ filters varied seasonally: in the

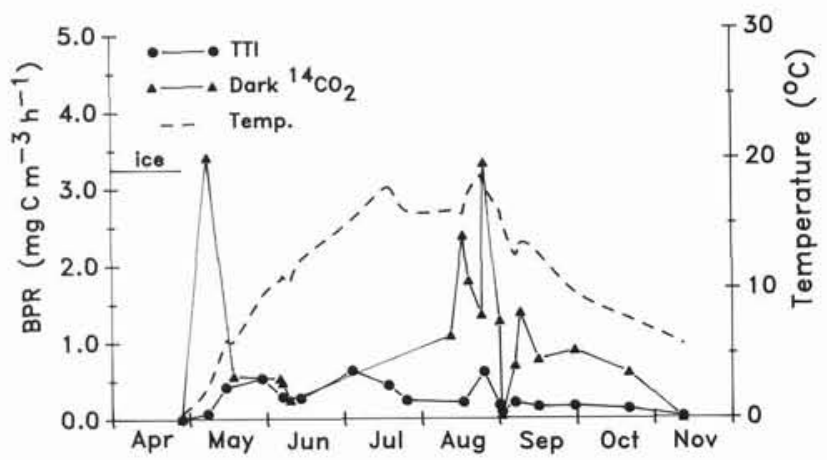

Fig. 4. Bacterial secondary productivity (BPR) and water temperature at $1 \mathrm{~m}$ depth in the Tvärminne archipelago in 1985. BPR was measured by the ${ }^{3} \mathrm{H}$-thymidine (TTI) and dark ${ }^{14} \mathrm{CO}_{2}$ uptake methods spring and late autumn, it corresponded to about $30 \%$ of total bacterial heterotrophic activity, while in the summer this value was about $10 \%$ (Fig. 5). The exceptionally high value of $52 \%$ measured in late August 1986 (Fig. 5) reflected a large average cell size of the bacteria after upwelling.

\section{Algal exudation}

\section{Net exudation}

In 1985, net exudation was $4.6 \%$ of the annual primary production (Table 2). The annual mean of the daily net exudation values expressed as a percentage of the current algal biomass was $7.5 \%$ (Table 3 ). The $\mathrm{EOC}_{\mathrm{n}}$ pool was largest in the summer, comprising $8.0 \%$ of the integral primary production, and $53 \%$ of the annual net exudation (Fig. 6, Table 2). During summer, the daily net exudation corresponded on average to $16.7 \%$ of the prevailing phytoplankton standing stock per day (Table 3 ). When controlled for temperature, the $\mathrm{EOC}_{\mathrm{n}}$ values were rather significantly correlated with primary productivity, while their correlation with algal biomass and bacterial productivity (TTI) was weak (Table 5).

Table 5. Partial correlations with net exudation and ${ }^{3} \mathrm{H}$-thymidine bacterial productivity, controlled for temperature, in the Tvärminne archipelago in 1985 and 1986. Values in brackets: number of cases; p: probability level; PBM: phytoplankton biomass; other explanations in Table 2

\begin{tabular}{|c|c|c|c|c|c|}
\hline \multicolumn{6}{|c|}{ Partial correlations with } \\
\hline \multicolumn{3}{|c|}{ Net exudation (18) } & \multicolumn{3}{|c|}{ Bacterial productivity (25) } \\
\hline & Corr. & $\mathrm{p}$ & & Corr. & $\mathrm{p}$ \\
\hline PPR & 0.4701 & 0.049 & PPR & 0.5049 & 0.010 \\
\hline TTI & 0.2882 & 0.246 & PBM & 0.3365 & 0.100 \\
\hline PBM & 0.2864 & 0.249 & & & \\
\hline
\end{tabular}

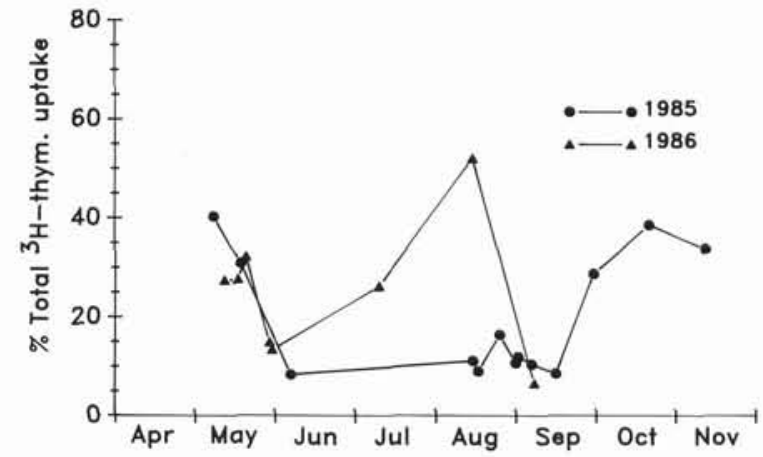

Fig. 5. Proportion of the bacterial heterotrophic activity retained on $0.8 \mu \mathrm{m}$ filters (in spring $1.0 \mu \mathrm{m}$ ) in the Tvärminne archipelago 


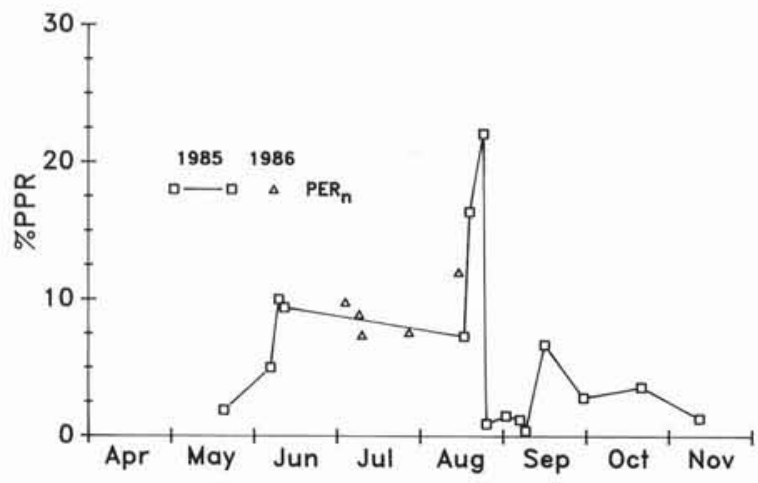

Fig. 6. Net percentage exudate release $\left(\mathrm{PER}_{n}\right)$ in the Tvärminne archipelago. Other explanations in Fig. 2

The net PER measurements were usually carried out with samples from only one depth. However, with the exception of early summer, the incubation depth did not have a significant effect on the proportion of organic ${ }^{14} \mathrm{C}$ remaining in the supernatants (in the early summer, 2-way ANOVA, $\mathrm{p}<0.05 ; 3$ or 4 incubation depths were evenly distributed along the percentage light attenuation gradient covering the upper 3 to $5 \mathrm{~m}$, and 3 or 4 experiments were carried out during each algal succession period). Thus the net PER values were considered to represent the whole trophogenic layer (about $10 \mathrm{~m}$ deep).

In July 1985, no fractionation measurements were carried out. During July and August 1986, the net PER values were similar to those for June and August 1985 (Fig. 6). Thus, the magnitude of the values obtained is probably representative of the summer minimum period in the Tvärminne area.

At the beginning of the late summer blue-green bloom, high net PER values (around $20 \%$ ) were obtained. During this period the algal cells were positively buoyant, which partly invalidated separation by centrifugation. The total organic ${ }^{14} \mathrm{C}$ of the supernatant was corrected for particulate ${ }^{14} \mathrm{C}$ in the $\mathrm{EOC}_{n}$ measurements. However, filtration on 0.2 um cellulose acetate filters was found to cause underestimation of particulate ${ }^{14} \mathrm{C}$ (Lignell \& Kuosa 1988), and thus the high net PER values were probably overestimates. At the end of the bloom, the blue-green algal cells were in a sinking phase, and low net PER values, of about $1 \%$, were recorded (Fig. 6).

\section{Bacterial uptake of exudates}

In 1985 , the total particulate organic ${ }^{14} \mathrm{C}$ in the 0.2 to $0.8 \mu \mathrm{m}$ fraction (measured as the difference between parallel filtrations) averaged $19.3 \%$ of primary productivity $(\mathrm{CV}=47 \%, \mathrm{n}=73)$. When these values were corrected for $<0.8 \mu \mathrm{m}$ autotrophic productivity (the ratios of the $<0.8 \mu \mathrm{m}$ algal biomass and productivity values to the corresponding total values in 1986 (Table 4) were applied to the $<0.8 \mu \mathrm{m}$ algal biomass values in 1985; Fig. 3), 10 to $20 \%$ of primary productivity appeared to be incorporated into free-living $(<0.8 \mu \mathrm{m})$ bacteria (data not shown). Depending on the method, the corresponding bacterial productivity values were in all but one case (TTI) or in more than $50 \%$ of the cases (dark ${ }^{14} \mathrm{CO}_{2}$ uptake) smaller than these corrected bacterial ${ }^{14} \mathrm{C}$ incorporation values. For unknown reasons, the parallel filtrations evidently resulted in a systematic overestimation of particulate organic ${ }^{14} \mathrm{C}$ in the 0.2 to $0.8 \mu \mathrm{m}$ fraction.

In 1988, values for bacterial incorporation of ${ }^{14} \mathrm{C}$ in the $<0.8 \mu \mathrm{m}$ fraction were considerably lower than those from 1985, when they were measured directly on the $<0.8 \mu \mathrm{m}$ filtrate and corrected for autotrophic productivity and net exudation (Fig. 7). As shown by Lignell (1990), this procedure should be used instead of the parallel filtrations used in 1985 in order to obtain reliable estimates for bacterial uptake of exudates. The relatively small seasonal variation in the proportion of organic ${ }^{14} \mathrm{C}$ incorporated into $<0.8 \mu \mathrm{m}$ bacteria in 1988 (Fig. 7) suggests that the mean value of about $1 \%$ of primary productivity is representative for the Tvärminne area. When this value was applied to 1985 data and a correction made for the proportion of attached bacteria (Fig. 5) and an assimilation efficiency of $50 \%$ (Coveney \& Wetzel 1989), the estimated bacterial uptake of exudates during different periods in 1985 was 2.2 to $2.8 \%$ of total primary production (primary production corrected for bacterial respiration associated with exudate uptake). Thus, in 1985 the annual total phytoplankton exudation $\left(\mathrm{EOC}_{\mathrm{n}}\right.$ in 1985 plus bacterial uptake of exudates based on corrections from 1988 data) was $7.1 \%$ of the total primary production (Table 2); correspondingly, the daily total exudation amounted on average to $10.8 \%$ of the current algal biomass (Table 3).

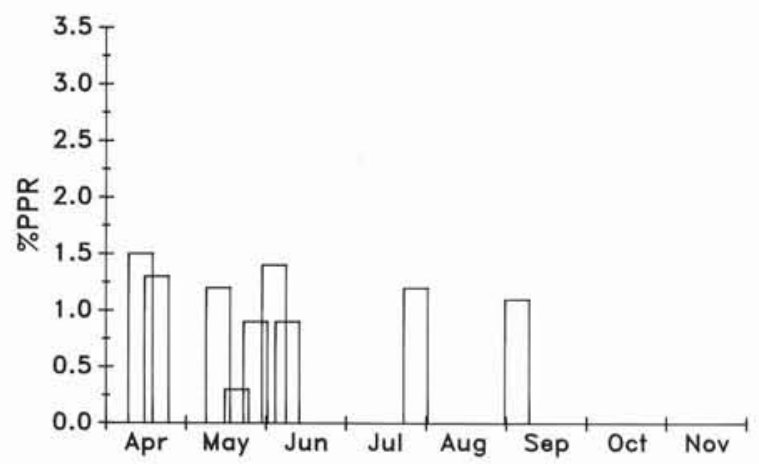

Fig. 7. Percentage of the primary productivity incorporated into free-living $(<0.8 \mu \mathrm{m})$ bacteria in the Tvärminne archipelago in 1988 


\section{Gel filtration}

All calibrations of the Sephadex columns were carried out at least twice (Table 6), and the replicate elution volumes differed by 0 to $2 \%$. In the G-15 column, glucose and glycine were eluted in the same volume $(120 \mathrm{ml})$ in spite of the difference in molecular weight (Table 6). This was at least partly due to the different shape of these compounds (Anon. 1977). Aromatic compounds are unique in that they interact with the inert gel matrix (Anon. 1977), which explains the relatively large elution volume of histidine (Table 6). Altogether, the calibrations showed, however, that even though the identification of individual compounds (e.g. amino acids and simple sugars) is not possible, the gel columns do effectively separate different molecular weight fractions.

Gel filtration with a G-50 column revealed that the dissolved exudate pool always consisted predominantly of small compounds, $<1500$ daltons (Fig. 8a, c, e, g; Table 6). Only during the late summer blue-green bloom was a distinct peak of large molecules (>10 000 daltons) recorded (Fig. 8e). However, clear signs of exudates larger than 1500 daltons were also found in spring and autumn (Fig. 8a, g).

Further examination with a G-15 column showed that compounds of about 300 to 600 daltons (corresponding to elution volumes of 97 to $115 \mathrm{ml}$ ) always formed the bulk of EOC $_{n}$ (Fig. 8b, d, f, h, Table 6). During the blue-green algal bloom, molecules of 1500 daltons were also excreted (Fig. 8e, f).

With the exception of the near-surface sample $(0.2 \mathrm{~m})$ in the spring, no clear qualitative difference in the size distribution of excreted compounds was observed in different depths in the spring and late summer samples (Fig. 8a, b, f); this supported the corresponding quantitative observations.

Table 6. Calibration of the Sephadex gel columns. Fractionation ranges: $\mathrm{G}-15=0$ to 1500 daltons, G-50 $=1500$ to 30000 daltons (proteins) or 500 to 10000 daltons (dextrans). DNAoligon.: DNA-oligonucleotide

\begin{tabular}{|llcc|}
\hline \multirow{2}{*}{ Column } & Compound & Mol. wt & Elution vol. (ml) \\
\hline \multirow{6}{*}{ G-15 } & Dextran Blue & Upper limit & 65 \\
& CoCl $_{3}$ & Lower limit & 135 \\
& Glycine & 75 & 120 \\
& Histidine & 155 & 134 \\
& Glucose & 180 & 120 \\
& Raffinose & 595 & 97 \\
& DNA-oligon. & 1302 & 75 \\
G-50 & Dextran Blue & Upper limit & 66 \\
& CoCl & Lower limit & 190 \\
& Cytochrome c & 12384 & 114 \\
& Myoglobine & 17800 & 107 \\
\hline
\end{tabular}

\section{DISCUSSION}

\section{Phytoplankton succession}

In 1985 , the succession of large $(>2 \mu \mathrm{m})$ algal species and the courses of the phytoplankton biomass and primary productivity (Table 1, Figs. 1 and 2) followed the pattern observed earlier off the SW coast of Finland (Niemi 1975, Kuparinen 1984, Kuosa \& Kivi 1989). Annual primary production $\left(84.2 \mathrm{~g} \mathrm{C} \mathrm{m}^{-2}\right)$ was within the range of 74 to $111 \mathrm{~g} \mathrm{C} \mathrm{m}^{-2}$ reported for the area by Kuparinen (1984) and Kuosa \& Kivi (1989). The present study was carried out at 2 sites, at Tvärminne Storfjärd during the spring and at Långskär during the rest of the year, but this was not of importance, as during the spring bloom the phytoplankton biomass, species composition and integral primary production are virtually the same in these places (with some differences in the timing of the biomass and productivity peaks; Niemi 1975).

In 1985, the biomass of picoalgae comprised on average $16.7 \%$ of the total (Table 3 ). Their importance was small during the algal blooms (about $1 \%$ in the spring and $9 \%$ in the late summer), while it was 17 to $26 \%$ during other periods (Tables 3 and 4). In 1986, the picoplankton productivity values averaged about $1 \%$ of the primary productivity in the spring and $24 \%$ in the summer (measured on the $<0.8 \mu \mathrm{m}$ fraction and corrected for the proportion of picoplanktonic algae $>0.8 \mu \mathrm{m} ;$ Table 4). These observations are similar to those made in the Stockholm archipelago, in the northern Baltic Sea (Larsson \& Hagström 1982) and in mesoeutrophic coastal marine waters (Stockner \& Antia 1986).

\section{Algal exudation}

In 1985, the annual net exudation amounted to $3.91 \mathrm{~g}$ $\mathrm{C} \mathrm{m}^{-2}$ or $4.6 \%$ of the primary production. This result agrees with the values of 4 to $5 \%$ obtained by Larsson \& Hagström (1982) in the Stockholm archipelago. Kuparinen (1984) reported annual net PER values of 13 to $30 \%$ in the Tvärminne area. However, he measured net exudation as the difference between the total (acidified sample) and particulate $(>0.2 \mu \mathrm{m}$ cellulose acetate filters) primary productivity, which leads to overestimation of net PER (Lignell \& Kuosa 1988).

In spring 1985, net exudation was measured only once (Fig. 7). However, the net PER value obtained $(1.9 \%)$ matches well with the mean values of about $2 \%$ found during the spring bloom in 1986 (Lignell 1990) and 1988 (unpubl.).

The highest percentage and absolute net exudation values were recorded during the summer minimum period (Fig. 7, Table 2). In summer, the carbon demand 
Fig. 8. Size fractionation of the dissolved exudate pool during the main stages of phytoplankton succession in the Tvärminne archipelago in 1985
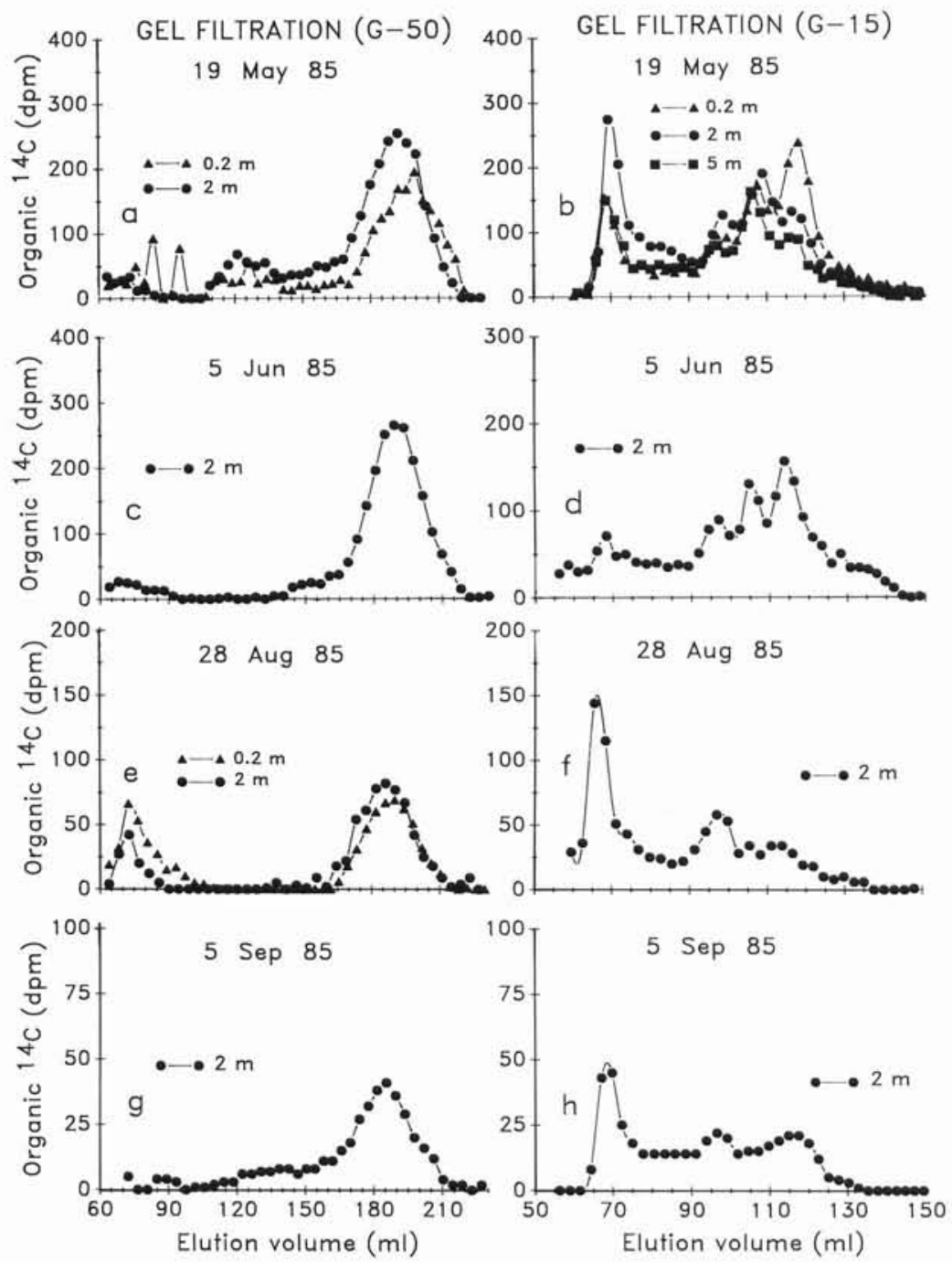

of heterotrophic nanoflagellates, the major grazers on bacterioplankton (Fenchel 1984, Wright \& Coffin 1984, Scavia \& Laird 1987), is also at its greatest (Kuosa \& Kivi 1989). Thus, the annual net exudation pattern fits the model presented by Wright (1988), in which a direct relationship between the grazing pressure on bacteria and their substrate concentration was predicted.

Throughout the productive period in 1988, about $1 \%$ of the primary productivity was incorporated into freeliving $(<0.8 \mu \mathrm{m})$ bacteria via ${ }^{14} \mathrm{C}$-labelled exudate uptake (Fig. 7). The values were within the range of 0.2 to $6 \%$ obtained by Berman \& Kaplan (1984), using a diffusion chamber technique. In spring, bacterial uptake of exudates was probably limited by the low water temperature (Hagström \& Larsson 1984, Scavia \& Laird 1987), but after that the fairly constant proportion of organic ${ }^{14} \mathrm{C}$ incorporated into bacteria indicated a balance between exudate uptake and bacterial grazing by nanoflagellates (cf. Wright 1988). Moreover, the dissolved exudates may also have become a limiting factor in the labelling of bacteria, as a part of the excreted compounds is refractory to bacterial degradation (e.g. Coveney \& Wetzel 1989).

The total annual PER (7.1\%, Table 2) was smaller than the corresponding values of 12 to $16 \%$ obtained by Larsson \& Hagström (1982) in the Stockholm archipelago, but it was within the range of 5 to $10 \%$ considered representative of coastal samples by Mague et al. (1980) and near the value of $5 \%$ accepted as realistic for eutrophic waters by Fogg (1983).

\section{Alternative sources of dissolved organics}

Several processes may lead to formation of dissolved organic carbon (DOC) from initial primary production (e.g. Williams 1981), and 2 potentially important alternative sources of labelled DOC in ${ }^{14} \mathrm{C}$ exudation meas- 
urements need to be commented here: First, it is possible that the exudation values obtained in 1985 partially reflected spillage of DOC via 'sloppy' feeding by zooplankton, since no prefractionation was carried out in order to remove zooplankton (cf. Lampert 1978, Jumars et al. 1989). This problem should be most severe during the summer, when zooplankton reach their biomass peak in the northern Baltic (e.g. Hagström \& Larsson 1984). However, in summer 1988, no significant difference was found between the PER values of the whole and $<20 \mu \mathrm{m}$ prefiltered samples (100 ml glass bottles), even though prefiltration removed from 90 to more than $99 \%$ of the total micro- and mesozooplankton biomass (unpubl.). Thus, while some phytoplankton carbon was evidently released by nanoflagellates and non-loricate ciliates passing $20 \mu \mathrm{m}$ filters in the 1988 experiments (cf. Caron et al. 1985), the overall contribution of 'sloppy' feeding by zooplankton to the labelled DOC pool was probably small in the type of experiments used in the 1985 and 1988 studies.

Second, natural algal communities comprise an unknown number of unhealthy or fragile cells, which could release labelled DOC in ${ }^{14} \mathrm{C}$ bottles via autolysis or cell breakage. In thorough examinations of this subject Mague et al. (1980) convincingly demonstrated, however, that exudation by natural phytoplankton populations is a real phenomenon, rather than representing just a portion of intact cells' contents (see also Coveney 1982).

Several time course ${ }^{14} \mathrm{C}$ exudation experiments carried out in the laboratory (constant light, in situ temperature) have shown that after the first 1 to $2 \mathrm{~h}$ PER values are virtually constant over periods of $24 \mathrm{~h}$ in the Tvärminne area (unpubl.). Also Mague et al. (1980) found a linear increase in $\mathrm{EOC}_{\mathrm{n}}$ pool with time, reflecting a dynamic relation between primary productivity and excretion of organic matter. The ${ }^{14} \mathrm{C}$ method measures photosynthesis of active algal cells. Thus, the observed time course patterns in exudate release indicated that autolysis of unhealthy cells or breakage of fragile cells due to containment shock were in general of minor importance in the 1985 experiments. Moreover, the incubation times of 6 to $7 \mathrm{~h}$ used in these experiments seem appropriate, as prolonged containment has been shown to cause additional problems in ${ }^{14} \mathrm{C}$ measurements (e.g. Venrick et al. 1977).

\section{Bacterial secondary production}

The annual net bacterial production (TTI) was $12.1 \mathrm{~g}$ $\mathrm{C} \mathrm{m}^{-2}$, or $14.4 \%$ of the primary production in the trophogenic layer. The percentage value is within the range of 10 to $15 \%$ recorded in the area by Kuparinen (1984) and Kuosa \& Kivi (1989), and it is close to the median value of $16.5 \%$ (mean $20 \%$ ) obtained in an extensive review by Cole et al. (1988).

On an annual basis, the TTI method resulted in a $69 \%$ smaller bacterial production value than the dark ${ }^{14} \mathrm{CO}_{2}$ uptake method (Table 2, Fig. 4). This is in accordance with earlier observations (e.g. Bell \& Kuparinen 1984, Riemann \& Søndergaard 1984). Nowadays, the dark ${ }^{14} \mathrm{CO}_{2}$ method is largely overlooked, because it is extremely sensitive to methodological artifacts and to the choice of conversion factor between ${ }^{14} \mathrm{CO}_{2}$ uptake and uptake of total organic carbon (Overbeck 1979, Riemann \& Søndergaard 1984). On the other hand, the TTI method gives conservative productivity estimates and involves many assumptions and uncertainties that have not yet been settled: for example, in the present study a ${ }^{3} \mathrm{H}$-thymidine conversion factor based on extensive data on coastal bacteria was

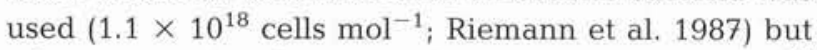
other conversion factors in the range of 2 to $5 \times 10^{18}$ cells $\mathrm{mol}^{-1}$ have frequently been reported (e.g. Fuhrman \& Azam 1982, Kirchman et al. 1982, Pedrós-Alió \& Newell 1989). Use of these higher conversion factors would have resulted in a TTI bacterial production value comparable to the one obtained with the dark ${ }^{14} \mathrm{CO}_{2}$ uptake method (46\% of the primary production; Table 2 ). The dark ${ }^{14} \mathrm{CO}_{2}$ value seems unrealistically high, however, since, assuming a carbon growth efficiency of $50 \%$, bacteria would have consumed $>90 \%$ of the primary production. Moreover, Kuparinen (1984) found by the method based on the frequency of dividing cells that on an annual basis the net bacterial production was $10 \%$ of the primary production in the Tvärminne archipelago.

Bacterial productivity (TTI) was significantly correlated with primary productivity, whereas its correlation with algal biomass was weak (Table 5). Also Cole et al. (1988) found bacterial productivity to be best explained by primary productivity. The results indicate that either algal and bacterial productivities were controlled by a common external factor not accounted for in the analysis (e.g. nutrient concentrations) or that a part of the newly produced photosynthates serves as an important substrate for bacteria.

Since the dissolved exudates were mainly small molecules (Figs. 8, Table 6), bacteria were probably able to use them as a preferred carbon source (Lancelot 1984). Thus exudation may explain the close correlation observed between algal and bacterial productivities (Table 5). The total exudation was $6.02 \mathrm{~g} \mathrm{C} \mathrm{m}^{-2}$ $\mathrm{yr}^{-1}$ (Table 2). If assimilation efficiency is assumed to be $50 \%$ (Coveney \& Wetzel 1989), the bacteria satisfied $25 \%$ (TTI) or $8 \%$ (dark ${ }^{14} \mathrm{CO}_{2}$ uptake) of their carbon demand via exudate uptake. The values are at the lower end of the results of 14 to $100 \%$ reported in other studies (Coveney 1982, Larsson \& Hagström 
1982, Jensen 1983, Bell \& Kuparinen 1984, Brock \& Clyne 1984, Søndergaard et al. 1988).

Algal exudation may be seriously underestimated if released compounds do not reach an isotopic equilibrium with the surrounding medium within the incubation time (Storch \& Saunders 1975). However, a considerable amount of evidence indicates that exudates are mainly derived from a small intracellular pool and rapidly reach isotopic equilibrium (Wiebe \& Smith 1977, Larsson \& Hagström 1979, Mague et al. 1980, Smith et al. 1986). Thus, in the Tvärminne area, bacteria must satisfy the major part of their carbon needs from other sources, probably to a great extent as byproducts released during zooplankton feeding (Lampert 1978, Jumars et al. 1989). Jumars et al. (1989) estimated that this carbon source corresponds to 10 to $50 \%$ of carbon fixation by phytoplankton. Moreover, a significant proportion ( $>10 \%)$ of 'dissolved' organic material presumably consists of non-living sub-micrometer particles (size range 0.38 to $1 \mu \mathrm{m}$ ), which are produced during grazing of bacteria by flagellates (Isao et al. 1990). It seems likely that these small particles provide an important source of carbon for pelagic bacteria (Isao et al. 1990, Toggweiler 1990). Other potential carbon sources for bacteria include autolysis products and detritus of autochthonous origin (especially during the spring bloom; Larsson 1986), and allochthonous material from local inflows of low-saline surface water (cf. Niemi 1975).

\section{Fractionation of bacterial heterotrophic activity}

The proportion of attached and large bacteria $(>0.8$ $\mu \mathrm{m})$ was about $30 \%$ in the spring and late autumn and about $10 \%$ in the summer (Fig. 5). In the Tvärminne area, the mean cell volume of the bacteria is largest during the spring (Virtanen 1985): in this period, rodshaped bacteria with a length greater than $1 \mu \mathrm{m}$ comprise 10 to $25 \%$ of the total bacterial numbers (Kuparinen pers. comm.), while in the summer these bacterial forms are scarce and small cocci are dominant (Virtanen 1985). In conclusion, the seasonal pattern in the retention of bacterial heterotrophic activity on $0.8 \mu \mathrm{m}$ filters (1.0 $\mu \mathrm{m}$ in the spring; Fig. 5) probably reflected differences in the mean bacterial cell size, rather than in the proportion of attached bacteria, and about $90 \%$ of the active bacteria were actually free-living.

\section{Nature of the exudation process}

Throughout the productive period in 1985, small compounds of 300 to 600 daltons were dominant in the EOC $_{\mathrm{n}}$ pool (Fig. 8, Table 6). In many other studies also,
$\mathrm{EOC}_{\mathrm{n}}$ pools have been found to consist mainly of small compounds of 500 to 900 daltons or less (Hellebust 1965, Søndergaard \& Schierup 1982, Iturriaga \& Zsolnay 1983, Jensen 1983). On the other hand, in 20 studies carried out by Lancelot (1984) in various marine environments, the amount of small $(<500$ daltons) excreted molecules averaged $23 \%$ (range 9 to $48 \%$ ) of the total excreted material. Moreover, Nalewajko \& Schindler (1976) found that exudates larger than 1500 daltons were dominant. The dominant algal species and the physiological stage of the phytoplankton seem to determine the nature of the excreted products (Hellebust 1965, Søndergaard \& Schierup 1982, Lancelot 1984).

A positive correlation was found between primary productivity and net exudation (Table 5), supporting the results of many other workers (e.g. Mague et al. 1980 and references therein). Net exudation was more closely correlated with algal than bacterial productivity, which fits the hypothesis that the rate of release of dissolved organic matter controls its equilibrium concentration (Fuhrman 1987). On the other hand, the poor correlation between phytoplankton biomass and exudation (Table 5) seems to contradict the suggestion of Bjørnsen (1988) that exudation could be interpreted as continuous loss from algal biomass ('property tax') rather than active release of excess photosynthates ('income tax').

Bjørnsen (1988) argued that the mechanism for exudation could be passive permeation through the cell membrane. By taking up exudates, the bacterioplankton increases the concentration gradient of these compounds across the algal cell membrane and thereby facilitates further excretion. In Bjørnsen's scenario planktonic bacteria thus act as parasites.

On theoretical grounds Bjørnsen (1988) concluded that passive (uncatalysed) leakage could account for an excretion rate of about $5 \%$ of phytoplankton carbon biomass per day. In the Tvärminne archipelago, in 1985, the daily total exudation averaged $10.8 \%$ of the current phytoplankton standing stock (Table 3). The measured total exudation value matched reasonably well with the theoretical one, when the tentative nature of the assumptions behind the latter value (Bjørnsen 1988 ) is taken into account.

The leakage rate of exudates is directly proportional to the permeability of the cell membrane (Bjørnsen 1988). The permeability of the lipid bilayer decreases steeply with increasing molecular size (Raven 1984), and consequently the validity of Bjørnsen's argumentation is strictly dependent on the size of the excreted molecules. Bjørnsen (1988) assumed that exudates are small metabolic intermediates (e.g. amino acids), whose permeability across the lipid bilayer would be about $10^{-9} \mathrm{~cm} \mathrm{~s}^{-1}$ or greater (cf. Raven 1984). However, 
even molecules of the size of glucose (180 daltons) have a permeability of $10^{-10} \mathrm{~cm} \mathrm{~s}^{-1}$ (see Raven 1984), which would allow a passive leakage of only $0.5 \%$ of the algal biomass per day.

In 1985, the gel filtration curves showed only minor signs of exudates of the size of small metabolic intermediates $(<100$ daltons, corresponding to an elution volume of $120 \mathrm{ml}$ or more; Fig. 8, Table 6). Throughout the productive period, the bulk of the dissolved exudate pool consisted of larger compounds (300 to 600 daltons or more), whose passive, non-mediated permeation (i.e. leakage) through the cell membrane is negligible (Raven 1984).

In steady state conditons, the volume of the $\mathrm{EOC}_{\mathrm{n}}$ pool is determined by the balance between the excretion rate and the bacterial uptake rate (Smith et al. 1986). It can be argued that small ( $<100$ daltons) excreted molecules were immediately taken up by bacteria (Azam \& Ammerman 1984, Fuhrman 1987), and thus they did not accumulate in the dissolved exudate pool. The major part of the phytoplankton exudation took place during the summer (Table 2), when the activity of the heterotrophic compartment of the plankton community is also highest. If it is assumed that the bacterial incorporation of ${ }^{14} \mathrm{C}$ in the $<0.8 \mu \mathrm{m}$ fraction (about $1 \%$ of the primary productivity; Fig. 7) was totally accounted for by compounds of $<100$ daltons, and if this value is corrected for attached bacteria $(10 \%$ in the summer; Fig. 5) and bacterial respiration (80\%, which in the case of small exudates is very high; see Williams 1984), the bacterial uptake of these compounds corresponded at most to $5.6 \%$ of the primary productivity.

Moreover, bacterial uptake of exudates was underestimated by the proportion of bacteria that were grazed during incubations. In the summer, the production of bacterial biomass can be assumed to be balanced by grazing by nanoflagellates (Fenchel 1984, Scavia \& Laird 1987). The number of new cells produced in $t$ hours $\left(C_{n}(t)\right)$ can be evaluated by the formula:

$$
\mathrm{C}_{\mathrm{n}}(\mathrm{t})=\mathrm{C}_{\mathrm{t}}(0) \times \ln 2 \times(\mathrm{t} / \mathrm{T})
$$

where $C_{t}(0)$ is the total number of bacteria at $t=0 ; T=$ the turnover time (h) of the bacterial biomass.

Assuming that the bacterial community grows at a turnover rate of about $1 \mathrm{~d}^{-1}$ (Wright \& Coffin 1984), the proportion of new bacteria $\left(\mathrm{C}_{\mathrm{n}}(\mathrm{t}): \mathrm{C}_{\mathrm{t}}(0)\right)$ that is produced in $6 \mathrm{~h}$ equals $(6 / 24) \times \ln 2=0.17$. Thus, in balanced conditions grazing by nanoflagellates would account for about $17 \%$ of the bacterial standing stock during the $6 \mathrm{~h}$ incubations used in the present study.

In summer 1985, the net exudation amounted to $8.0 \%$ of the primary production (Table 2). Even if the upper approximation for bacterial uptake of small
( $<100$ daltons) exudates (5.6\% of algal biomass) was corrected for the proportion of grazed bacteria (17\%), the major part of the excreted compounds would still have consisted of molecules of 300 to 600 daltons and larger (Fig. 8c, d, Table 6). Consequently, excretion of organic compounds through the cell membrane must have taken place mainly via mediated transport, requiring protein catalysts (cf. Raven 1984), rather than via uncatalysed leakage as suggested by Bjørnsen (1988).

Evidence of the existence of some form of control of the exudation process comes from the observations that in the case of small compounds also, such as amino acids, the composition of their intracellular pool differs from that of the excreted pool outside the cell (Mague et al. 1980, Jensen et al. 1985). Even the premeability of the plasmalemma may be controlled: Brown et al. (1982) showed that while the permeability of the lipid bilayers of glycerol (92 daltons) was $5 \times 10^{-6} \mathrm{~cm} \mathrm{~s}^{-1}$, the corresponding value for the plasmalemma of Dunaliella was $5 \times 10^{-11} \mathrm{~cm} \mathrm{~s}^{-1}$.

Wood \& Van Valen (1990) recently hypothesized that algal exudation will only take place under conditions of high light intensity and nutrient scarcity, where exudation would serve as an alternative mechanism for photorespiration (i.e. instead of being photorespired the photosynthates produced in excess of storage capacity will be excreted outside the cell). Wood \& Van Valen (1990) further suggested that algal exudation and nutrient uptake processes are temporally and spatially separated in oligotrophic oceans: diffusive flows result in frequent excursions of algal cells between the surface (upper $20 \mathrm{~m}$ layer), where exudation is expected (high light and low nutrient concentrations), and the thermocline/nutricline, where nutrient assimilation takes place and no exudation is expected (low light and high nutrient concentrations). Thus, algae would not exude and hence stimulate bacterial activity and competition for nutrients (cf. Bratbak \& Thingstad 1985 ) at the same time, when they are satisfying their own demand for nutrients.

The theory of Wood \& Van Valen (1990) predicts formation of patches of algae and bacteria in the surface layer, which are fuelled by exudation. Their theory does not assume any feedback mechanism between algal exudation and bacterial uptake of excreted compounds. However, the existence of such a mechanism seems most plausible in the light of recent literature.

When the carbon cycling and energy flow in planktonic ecosystems is considered, the primary consequence of excretion of organic matter is attraction of bacteria to algal cells (Azam \& Ammerman 1984). The apparent disadvantage of having bacteria with higher nutrient uptake efficiency in the vicinity of algal cells (Bratbak \& Thingstad 1985, Bjørnsen 1988) is overcome 
by strict control of the bacteria by grazing nanoflagellates (Pengerud et al. 1987). In connection with this grazing, nutrients incorporated in bacteria are released in the surrounding water and thus become available to the algal cells (Sherr et al. 1988). Moreover, bacterial exoenzymes release nutrients from dissolved organic compounds (Ammerman \& Azam 1985), and bacteria excrete compounds (e.g. vitamins) that can be vital to the growth of algae (Haines \& Guillard 1974).

The results of Larsson \& Hagström (1982) and the present study fit this scenario: the highest absolute and percentage exudation values were recorded in the summer, when the nutrient concentrations are very low. On the other hand, in the spring, when the nutritional situation is better for algae, exudation is of minor importance. These results also fit the hypothesis of Wood \& Van Valen (1990), where nutrient scarcity was considered a prerequisite for exudation of organic matter from algal cells.

In conclusion, algal exudation represents an important source of information in the communication network of planktonic communities. The exudation link between algal and bacterial cells evidently results in mutual gain, which in part explains the existence of such a process under natural conditions.

Acknowledgements. Thanks are due to Dr T. Tamminen for his skilful assistance in the field and to Dr H. Kuosa for his careful microscopic determinations; both of them also made good comments on the manuscript. In addition, I am grateful to Drs B. Riemann, J. Kuparinen, S. Kaitala, I. Norros and H. Nyberg for their valuable remarks. The linguistic form was checked by Mrs A. Damström. This study is a contribution of the project PELAG, and was financed by Maj and Tor Nessling foundation, and the Academy of Finland.

\section{LITERATURE CITED}

Ammerman, J. W., Azam, F. (1985). Bacterial 5'-nucleotidase in aquatic ecosystems: a novel mechanism of phosphorus regeneration. Science 227: 1338-1340

Anon. (1977). Gel filtration theory and practice. Pharmacia Fine Chemicals $\mathrm{AB}$, Uppsala

Azam, F., Ammerman, J. W. (1984). Cycling of organic matter by bacterioplankton in pelagic marine ecosystems: microenvironmental considerations. In: Fasham, M. J. R. (ed.) Flows of energy and materials in marine ecosystems. Plenum, New York, p. 345-360

Bell, R. T. ( 1986). Further verification of the isotope dilution approach for estimating the degree of participation of $\left[{ }^{3} \mathrm{H}\right]$ thymidine in DNA synthesis in studies of aquatic bacterial production. Appl. environ. Microbiol. 52: 1212-1214

Bell, R. T., Kuparinen, J. (1984). Assessing phytoplankton and bacterioplankton production during early spring in Lake Erken, Sweden. Appl. environ. Microbiol. 48: 1221-1230

Berman, T., Kaplan, B. (1984). Diffusion chamber studies of carbon flux from living algae to heterotrophic bacteria. Hydrobiol. 108: 127-134

Bjørnsen, P. K. (1986). Bacterioplankton growth yield in con- tinuous seawater cultures. Mar. Ecol. Prog. Ser. 30: 191-196

Bjørnsen, P. K. (1988). Phytoplankton exudation of organic matter: why do healthy cells do it? Limnol. Oceanogr. 33: $151-154$

Bratbak, G., Thingstad, T. F. (1985). Phytoplankton-bacteria interactions: an apparent paradox? Analysis of a model system with both competition and commensalism. Mar. Ecol. Prog. Ser. 25: 23-30

Brock, T. D., Clyne, J. (1984). Significance of algal excretory products for growth of epilimnetic bacteria. Appl. environ. Microbiol. 47: 731-734

Brown, F. F., Sussmann, I., Avron, M., Degani, H. (1982). NMR studies of glycerol permeability in lipid vesicles, erythrocytes and the alga Dunaliella. Biochim. biophys. Acta 690 : 165-173

Caron, D. A., Goldman, J. C., Andersen, O. K., Dennett, M. R. (1985). Nutrient cycling in a microflagellate food chain: II. Population dynamics and carbon cycling. Mar. Ecol. Prog. Ser. 24: 243-254

Cole, J. J., Findlay, S., Pace, M. L. (1988). Bacterial production in fresh and saltwater ecosystems: a cross-system overview. Mar. Ecol. Prog. Ser. 43: 1-10

Coveney, M. F. (1982). Bacterial uptake of photosynthetic carbon from freshwater phytoplankton. Oikos 38: 8-20

Coveney, M. F., Wetzel, R. G. (1989). Bacterial metabolism of algal extracellular carbon. Hydrobiol. 173: 141-149

Davis, P. G., Sieburth, J. McN. (1982). Differentiation of phototrophic and heterotrophic nanoplankton populations in marine waters by epifluorescence microscopy. Ann. Inst. oceanogr. 58 (Suppl.): 249-260

Edler, L:, Hälfors, G., Niemi, Å. (1984). A peliminary check-list of the phytoplankton of the Baltic Sea. Acta Bot. Fennica 128: $1-26$

Fenchel, T. (1984). Suspended marine bacteria as a food source. In: Fasham, M. J. R. (ed.) Flows of energy and materials in marine ecosystems. Plenum, New York, p. 301-315

Fogg, G. E. (1983). The ecological significance of extracellular products of phytoplankton photosyntheses. Botanica mar. 26: $3-14$

Fuhrman, J. (1987). Close coupling between release and uptake of dissolved free amoni acids in seawater studied by an isotope dilution approach. Mar. Ecol. Prog. Ser. 37: $45-52$

Fuhrman, J., Azam, F. (1982). Thymidine incorporation as a measure of bacterioplankton production in marine surface waters: evaluation and field results. Mar. Biol. 66: 109-120

Hagström, Å., Larsson, U. (1984). Diel and seasonal variation in growth rates of pelagic bacteria. In: Hobbie, J. E., Williams, P. J. leB. (eds.) Heterotrophic activity in the sea. Plenum, New York, p. 249-262

Haines, K. C., Guillard, R. R. L. (1974). Growth of vitamin B $B_{12}$ requiring marine diatoms in mixed laboratory cultures with vitamin $\mathrm{B}_{12}$-producing marine bacteria. J. Phycol. 10: 245-252

Hellebust, J. A. (1965). Excretion of some organic compounds by marine phytoplankton Limnol. Oceanogr. 10: 192-206

Hopkinson, C. S. Jr, Sherr, B., Wiebe, W. J. (1989). Size fractionated metabolism of coastal microbial plankton. Mar. Ecol. Prog. Ser. 51: 155-166

Isao, K., Hara, S., Terauchi, K., Kogure, K. (1990). Role of submicrometre particles in the ocean. Nature, Lond. 345: 242-244

Iturriaga, R., Zsolnay, A. (1983). Heterotrophic uptake and transformation of phytoplankton extracellular products. Botanica mar. 26: 375-381 
Jensen, L. M. (1983). Phytoplankton release of extracellular organic carbon, and bacterial assimilation. Mar. Ecol. Prog. Ser, 11: $39-48$

Jensen, L. M., Jørgensen, N. O. G., Søndergaard, M. (1985). Specific activity. Significance in estimating release rates of extracellular dissolved organic carbon (EOC) by algae. Verh. int. Verein. Limnol. 22: 2893-2897

Jumars, P. A., Penry, D. L., Baross, J. A., Perry, M. J., Frost, B. W. (1989). Closing the microbial loop: dissolved carbon pathway to heterotrophic bacteria from incomplete ingestion, digestion and absorption in animals. Deep Sea Res. 36: $483-495$

Kirchman, D., Ducklow, H. W., Mitchell, R. (1982). Estimates of bacterial growth from changes in uptake rates and biomass. Appl. environ. Microbiol. 44: 1296-1307

Kuosa, H., Kivi, K. (1989). Bacteria and heterotrophic flagellates in the pelagic carbon cycle in the northern Baltic Sea. Mar. Ecol. Prog. Ser. 53: 93-100

Kuparinen, J. (1984). Annual and seasonal fluctuation of primary productivity and overall respiration in a pelagic plankton community off Tvärminne, SW coast of Finland. Ophelia, Suppl. 3: 111-112

Kuparinen, J. (1988). Development of bacterioplankton during winter and early spring at the entrance to the Gulf of Finland, Baltic Sea. Verh. int. Verein. Limnol. 23: 1869-1878

Kuznetsov, S. I., Romanenko, V. I. (1966). Produktion der Biomasse heterotropher Bakterien und die Geschwindigkeit ihrer Vermehrung im Rybinsk-Stausee. Verh. int. Verein. Limnol. 16: 1493-1500

Lampert. W. (1978). Release of dissolved organic carbon by grazing zooplankton. Limnol. Oceanogr. 23: 831-834

Lancelot, C. (1984). Extracellular release of small and large molecules by phytoplankton in the southern bight of the North Sea. Estuar. coast. Shelf Sci. 18: 65-77

Larsson, U. (1986). The pelagic microheterotrophic food web in the Baltic Sea: bacteria and their dependence on phytoplankton. Ph. D. thesis, Univ. Stockholm

Larsson, U., Hagström, A. (1979). Phytoplankton exudate release as an energy source for the growth of pelagic bacteria. Mar. Biol. 52: 199-206

Larsson, U., Hagström, Å. (1982). Fractionated phytoplankton primary production, exudate release and bacterial production in a Baltic eutrophication gradient. Mar. Biol. 67: $57-70$

Lehman, J. T., Botkin, D. B., Likens, G. E. (1975). The assumptions and rationales of a computer model of phytoplankton population dynamics. Limnol. Oceanogr. 20: 343-364

Lignell, R. (1990). Algal exudation and its relationship to bacterial production during vernal phytoplankton blooms. Arch. Hydrobiol. Beih. Ergebn. Limnol. 34: 53-59

Lignell, R., Kuosa, H. (1988). Sources of error in algal exudation measurements. Arch. Hydrobiol. Beih. Ergebn. Limnol. 31: 97-104

Mague, T. H., Friberg, E., Hughes, D. J., Morris, I. (1980). Extracellular release of carbon by marine phytoplankton; a physiological approach. Limnol. Oceanogr. 25: 262-279

Nalewajko, C., Schindler, D. W. (1976). Primary production, extracellular, release, and heterotrophy in two lakes in the ELA, Northwestern Ontario. J. Fish. Res. Bd Can. 33: 219-226

Niemi, M., Kuparinen, J., Uusi-Rauva, A., Korhonen, K. (1983). Preparation of algal samples for liquid scintillation counting. Hydrobiol. 106: 149-156

Niemi, A. (1975). Ecology of phytoplankton in the Tvärminne area, SW coast of Finland. II. Primary production and environmental conditions in the archipelago and the sea zone. Acta Bot. Fennica 105: 1-73

Overbeck, J. (1979). Dark $\mathrm{CO}_{2}$ uptake - biochemical background and its relevance to in situ bacterial production. Arch. Hydrobiol. Beih. Ergebn. Limnol. 12: 38-47

Pedrós-Alió, C., Newell, S. Y. (1989). Microautoradiographic study of thymidine uptake in brackish waters around Sapelo Island, Georgia, USA. Mar. Ecol. Prog. Ser. 55: 83-94

Pengerud, B., Skjoldal, E. F., Thingstad, T. F. (1987). The reciprocal interaction between degradation of glucose and ecosystem structure. Studies in mixed chemostat cultures of marine bacteria, algae, and bacterivorous nanoflagellates. Mar. Ecol. Prog. Ser. 35: 111-117

Raven, J. A. (1984). Energetics and transport in aquatic plants. Alan R. Liss, New York

Riemann, B., Bjørnsen, P. K., Newell, S., Fallon, R. (1987). Calculation of cell production of coastal bacteria based on measured incorporation of ${ }^{3} \mathrm{H}$-thymidine. Limnol. Oceanogr. 32: 471-476

Riemann, B., Søndergaard, M. (1984). Measurements of diel rates of bacterial secondary production in aquatic environments. Appl. environ. Microbiol. 47: 632-638

Scavia, D., Laird, G. A. (1987). Bacterioplankton in Lake Michigan: dynamics, controls, and significance to carbon flux. Limnol. Oceanogr. 32: 1017-1033

Sherr, B. F., Sherr, E. B., Hopkinson, C. S. (1988). Trophic interactions within pelagic microbial communities: indications of feedback regulation of carbon flow. Hydrobiol. 159: $19-26$

Sieburth, J. McN. (1977). International Helgoland Symposium: convener's report of the informal session on biomass and productivity of micro-organisms in planktonic ecosysems. Helgoländer wiss. Meeresunters. 30: 697-704

Sieburth, J., Smetacek, V., Lenz, J. (1978). Pelagic ecosystem structure: heterotrophic compartments of the plankton and their relationship to plankton size fractions. Limnol. Oceanogr. 23: 1256-1263

Smith, R. E. H., Harrison, W. G., Irwin, B., Platt, T. (1986). Metabolism and carbon exchange in microplankton of the Grand Banks (Newfoundland). Mar. Ecol. Prog. Ser. 34: 171-183

Søndergaard, M. \& 12 others (1988). Pelagic food web processes in an oligotrophic lake. Hydrobiol. 164: 271-286

Søndergaard, M., Schierup, H.-H. (1982). Release of extracellular organic carbon during a diatom bloom in Lake Mossø: molecular weight fractionation. Freshwater Biol. 12: $313-320$

Sorokin, Y. I. (1965). On the heterotrophic role of chemosynthesis and bacterial biosynthesis in water bodies. Mem. Ist. Ital. Idrobiol. 18: 187-205

Sorokin, Y. I. (1978). Decomposition of organic matter and nutrient regeneration. In: Kinne, O. (ed.) Marine ecology, Vol. IV, Dynamics. Wiley, Chichester, p. 501-616

Stabel, H. H. (1977). Gebundene Kohlenhydrate als stabile Komponenten im Schöhsee und in Scenedesmus-Kulturen. Arch. Hydrobiol. Suppl. 53: 159-254

Steele, J. H. (1974). The structure of marine ecosystems. Harvard University Press, Cambridge

Steemann Nielsen, E. (1952). The use of radioactive carbon $\left({ }^{14} \mathrm{C}\right)$ for measuring organic production in the sea. J. Cons. perm. int. Explor. Mer. 18: 117-140

Stockner, J. G., Antia, N. J. (1986). Algal picoplankton from marine and freshwater ecosystems: a multidisciplinary perspective. Can. J. Fish. Aquat. Sci. 43: 2472-2503

Storch, T. A., Saunders, G. W. (1975). Estimating daily rates of extracellular dissolved organic carbon release by phyto- 
plankton populations. Verh. int. Verein. Limnol. 19: 952-958

Strayer, D. (1988). On the limits to secondary production. Limnol. Oceanogr. 33: 1217-1220

Toggweiler, J. R. (1990). Diving into the organic soup. Nature, Lond. 345: 203-204

Untermöhl, H. (1958). Zur Vervollkommung der quantitativen Phytoplanktonmethodik. Mitt. int. Verein. theor. angew. Limnol. 9: 1-38

Venrick, E. L., Beers, J. R., Heinbokel, J. F. (1977). Possible consequences of containing microplankton for physiological rate measurements. J. exp. mar. Biol. Ecol. 26: 55-76

Virtanen, A. (1985). Bacterial numbers, biomass, activity and production at a site in the Tvärminne area of the Gulf of Finland. Aqua Fennica 15: 143-160

Wiebe, W., J., Smith, D. F. (1977). Direct measurement of dissolved organic carbon release by phytoplankton and incorporation by microheterotrophs. Mar. Biol. 42: 213-223

Williams, P. J. leB. (1981). Incorporation of microheterotrophic processes into the classical paradigm of the planktonic food web. Kieler Meeresforsch., Sonderh. 5: 1-28

This article was submitted to the editor
Williams, P. J. leB. (1982). Microbial contribution to overa plankton community respiration - studies in enclosure In: Grice, G. D., Reeve, M. P. (eds.) Marine mesocosm Springer, Berlin, p. 305-321

Williams, P. J. leB, (1984). Bacterial production in the marin food chain: the emperor's new suite of clothes? In: Fasham M. J. R. (ed.) Flows of energy and materials in marinı ecosystems. Plenum, New York, p. 271-299

Wintermans, J. F. G. M., Demots, A. (1965). Spectrophotomet. ric characteristics of chlorophyll $a$ and $b$ and thein phaeophytins in ethanol. Biochim. biophys. Acta 109: 448-453

Wood, A. M., Van Valen, L. M. (1990). Paradox lost? On the release of energy-rich compounds by phytoplankton. Mar. Microb. Food Webs 4: 103-116

Wright, R. T. (1988). A model for short-term control of the bacterioplankton by substrate and grazing. Hydrobiol. 159: 111-117

Wright, R. T., Coffin, R. B. (1984). Measuring microzooplankton grazing on planktonic marine bacteria by its impact on bacterial production. Microb. Ecol. 10: 137-149

Manuscript first received: May 8, 1990

Revised version accepted: August 29, 1990 